\title{
Towards Creating Sustainable Ecotourism Interventions: Practical Lessons from Mesomagoro, Ghana
}

\author{
Kwaku Adutwum Ayim Boakye \\ University of Cape Coast, Ghana \\ Kwaku.boakye@ucc.edu.gh \\ DOI//http://dx.doi.org/10.4314/gjds.v14i1.5
}

\begin{abstract}
Ecotourism has, over the past three decades, been employed globally as a tool to secure a balance between the need for environmental preservation and the sustenance of the communities which depend directly on it. Consequently, the trend has been to designate natural resources as Protected Areas, limit access to them and regulate their use. While this approach has been successful in protecting the ecological integrity of the said spaces, the same cannot be said for the livelihoods of persons living in such areas. Consequently, the literature is almost unanimous with the verdict that ecotourism has not worked in the African context resulting in deep discontent which tends to be expressed in varying ways among the host communities. However, one notable exception to this trend can be found in Mesomagoro, a small community in Ghana that still views ecotourism relatively positively after 20 years of hosting an intervention. Using the Sustainable Livelihoods Concept and a qualitative approach, this study sought to understand the reasons that could account for ecotourism's success in Mesomagoro. It employs the Purposive Sampling Technique and uses In-depth Interview Schedules and Focus Group Discussions to elicit the relevant information. It was found that the sustainability of the intervention and the subsequent widely positive views of the community are primarily attributable to the fact that the project was designed to both integrate tourism into the existing livelihoods and skill sets and also to enhance their adaptive capabilities. It is recommended that ecotourism interventions in Africa should be designed to understand the local context and integrate programmes into existing livelihoods and not the other way round.
\end{abstract}

Keywords: Tourism, Development, Livelihoods, Assets, Adaptive Capabilities

\section{Introduction}

Maintaining a mutually beneficial balance between the conservation of natural resources and the livelihoods of populations that surround and depend on them remains both a topic of endless polemic debate in theory and a slippery path to pursue in practice. Cernea and Schmidt-Soltau (2003: 42) describe this dilemma as both 'vexing' and difficult to solve. For Laudati (2010: 740), it represents a 'conundrum and a contradiction'. 
To address the dilemma, Ecotourism has often been employed as a strategy to address the competing interests between the two legitimate demands and the tactic has often been the creation of Protected Areas (PAs) (Coad, Campbell, Miles \& Humphries, 2008). Under this method, areas of ecological significance are designated, created and either regulated under strict supervision or entirely protected from human access and use. This trend is particularly true of Sub Saharan Africa (SSA) (Asiedu, 2002, Kiss, 2004; Carruthers, 2007) where governments and development agencies have sought to use ecotourism to simultaneously protect the environment and pursue socio-economic development. According to a World Conservation Monitoring Centre Report (2004), the total PA coverage in Sub Saharan Africa (SSA) has almost doubled to the current 3.06 million $\mathrm{km}$-squared since 1970.

The ecotourism paradigm has been widely accepted and employed by major international developmental agencies such as The World Bank and United Nationsbased Global Environmental Facility (GEF) (Rembert, 1997), United States Agency for International Development (USAID), and the European Commission and this belief has shown in the massive investments made. According to Kiss (2004), by the mid-1990s, USAID had 105 projects with ecotourism components, totalling US\$2 billion. Similarly, 32 of the 55 World Bank-financed projects that supported Protected Areas (PAs) in Africa between 1988 and 2003 included a Community-Based Ecotourism component. The European Commission (2010) claims on its website to have funded most of the biggest and successful programmes to support conservation and PAs management - i.e. ECOFAC in Central Africa ( $€ 115 \mathrm{M}$ in 15 years) and ECOPAS in Western Africa ( $€ 24 \mathrm{M}$ in 7 years). Ecotourism's highest endorsement came from no less a body as the United Nations' General Assembly which, in December, 2012, passed a resolution recognising it as key in the fight against poverty, the protection of the environment and the promotion of sustainable development.

The thrust of the argument in support of ecotourism has always been predicated on its ability to create a 'win-win' situation in which environmental conservation, local economic development and poverty reduction are achieved simultaneously (e.g. Boo, 1990; Honey, 1999; Honey \& Gilpin 2009). Expanding the frontiers, Sarskar and George (2010: 37 ) suggest that "alternative tourism leads to communal harmony, wildlife and heritage conservation, and socio-cultural and socio-economic development of local communities".

However, in spite of its perceptible benefits (e.g. Ogutu, 2002), the costs of ecotourism especially to the livelihood of populations which depend on the immediate environment are high and sometimes tragic. As Kuenzi and McNeely (2008) assert, the shocks, hazards and costs of ecotourism are often overlooked or ignored by policy makers and planners. The Kakum National Park (KNP), one of the most popular ecotourism sites in 
Africa, was carved out of the Kakum Conservation Area in the early 1990s as part of a project which sought to use tourism as a tool to spearhead economic development in Ghana's Central Region. As is typical of ecotourism interventions, it reflected the double aim of conserving the forest-based natural resources and creating economic opportunities for the inhabitants within the catchment areas of the Park. Attempts were made by Government of Ghana and other development partners to provide support for local residents who lost livelihoods as a result of the gazettal of the Kakum Conservation Area (Cobbinah, Black \& Thwaites, 2015). Hence, most of the over 20 communities surrounding the park have hosted one tourism -related project or the other (e.g. observation platforms, folklore, hiking trails among others). In spite of these interventions, studies that have elicited community opinions about the Park over the years (e.g. (Dei, 2000; Bediako, 2000; Asiedu, 2002; Boakye, 2008; Eshun, 2011) point to pervasive negative sentiment. These sentiments have often resulted in agitations and threats of destruction of the Park. The most recent being in September, 2016 where it was widely reported in the Ghanaian media that farmers in some communities surrounding the park had threatened to burn it down on account of the fact that elephants from the park were destroying their cocoa farms.

However, a notable departure from this trend has been found in Mesomagoro - one of the adjoining communities where repeated studies have singled out this community as having relatively positive sentiments about ecotourism and stronger support for environmental conservation. Such a deviation from the general trend beckons closer scrutiny and begets the following questions: Is the community as exposed to similar ecotourism-related shocks as the others? Have there been any benefits from ecotourism? And, if so, what strategies have been used in rendering such benefits useful and available to a wide section of the community? Why do the inhabitants of Mesmoagoro (in contravention to the conventional trends established in the literature) still have positive sentiments almost 25 years after the interventions were made?

Host sentiments are often used to gauge support or otherwise of the community for ecotourism. In consonance with general exchange theories it has been traditionally established (e.g. Ap, 1992) that there is an organic link between economic benefits and host community sentiments about tourism. Sentiments about tourism are generally held to be positive by persons or communities who see and feel the economic gains from the trade (Amuquandoh, 2010; Xu, Barbieri, Anderson, Leung and Rozier-Rich, 2016) and vice-versa. For reasons that will be explored in detail later in this paper, the general sentiment about ecotourism in Africa has been largely negative.

As the academic community continues to search for ways to make ecotourism a truly viable option, a study of this nature echoes the repeated calls (e.g. Akyeampong, 2011; Coriaa \& Calfucurab, 2012) for a better approach in managing the trade-offs between 
conservation and livelihoods. This paper seeks to explore the unique dynamics of the Mesomogoro case within the context of highlighting the reasons that could account for such unusually positive sentiment.

\section{Literature Review}

\section{Dynamics of Ecotourism-related Shocks}

Tourism has generally evolved into two forms: the traditional mass and the alternative paradigms. Alternative tourism products emerged out of concerns for the destruction of the environment attributable to mass tourism, and have been often promoted (e.g. Honey, 2009) as a surer and greener way for poor countries to pursue socio-economic development. Generally, alternative tourism is predicated on the belief that greener, smaller scale tourism that engages the local communities is more likely to produce better and lasting benefits to the host.

Ecotourism is, perhaps, the single most recognisable form of alternative tourism. The International Ecotourism Society defines ecotourism as responsible travel to natural areas that conserves the environment and improves the well-being of local people. Though in its broadest form and strictest application the term 'ecotourism' would include visits to cultural and heritage sites (Boo, 1990), its use has normally been synonymous with nature-based tourism and, it has also come to be a generic representation of all forms of 'alternative tourism'. Though concerns have been raised (e.g. Burns, 2004) about the clarity of the concept and the sustainability of its practice, ecotourism remains a popular development strategy.

Ecotourism, generates shocks but this fact is often obscured by the hyping of the few success stories over the real costs (Kuenzi \& McNeely 2008) or completely ignored (Blaikie et al. 1994). Even where benefits have been realised, they have been criticized as been too marginal and skewed towards a few local elite (Cobbinah, Black and Thwaites, 2015, Eshun and Tagoe-Darko, 2015; Kiss, 2004).There is a political-ecology centred critical literature (e.g Laudati, 2010, Pleumarom, 2012) which argues that ecotourism rather serves as a conduit for underdevelopment.

In fact, the thrust of the empirical evidence in SSA highlights the inability of ecotourism to secure or protect local livelihoods (Abane, Awusabo Asare and Kissi, 1999; Dei, 200 Eshun, 2011; Twerefour and Ababio, 2012; Amoah and Wiafe, 2012). The pervasive nature of the 'failure' rate prompted radical policy revisions on the use of ecotourism by major multilateral development agencies such as the World Bank and the Asian Development Bank in 2004 (Cernea, 2006). Generally, it is the case that benefits of ecotourism appear to be unduly romanticised and, where plausible, have been only limited to securing 
environmental protection at the expense of population livelihoods (Koens, Dieperink and Mirinda 2009; McLaughlin , 2011:1).

Within the context of SSA, the literature identifies two generic ecotourism-related shocks which are discussed in turn. The first relates to displacement (both physical and economic) (Coad, Campbell, Miles and Humphries, 2008; Nelson, 2012). Though a highly contested concept, displacement as used in this context, involves forcing locals to relocate to places which are less suitable for earning a living from the land (Agarwal and Redford, 2009; Kuenzi and McNeely, 2008) which normally results in debilitating consequences (Lasgorceix, and Kothari, 2009) for their livelihoods. Key examples of this eco-tourism-induced hazard have occurred in Ghana where six villages were evicted to make way for the Mole National Park (Mason and Danso, 1995), Ethiopia and Botswana (Adams and Hutton, 2007) Cameroun (Schmidt-Soltau, 2005) and Congo (Cernea, 2003). Kenya (Ogutu, 2002, Odinha, 2010) and South Africa (Carruthers, 2007).

The second (and, perhaps, more debilitating) ecotourism-related shock comes in the form of a disruption of normal livelihoods (Cernea, 2006, Boakye, 2008, Torri, 2011). Such disruption occurs when access to hitherto freely available resources is curtailed to make room for tourism-related development (Schmidt-Soltau 2003). This shock is widely reported as synonymous with ecotourism development in indigenous and ethnic communities (Cernea and Schmidt-Soltau 2003; Pleumarom, 2012; McLaughlin 2011; Coriaa \& Calfucurab 2012) and is particularly pervasive in the study area (e.g. Eshun, 2011, Amoah and Wiafe, 2012). These shocks combine to make the host communities vulnerable. But another dimension of the problem has to do with the fact that they have limited capacities to either withstand the shocks or to take advantages of the opportunities offered by ecotourism.

\section{Host Community Vulnerabilities and Capacities Relative to Ecotourism Development}

It is trite knowledge that host communities form an integral of the tourism product (Blackstock, 2005; Murphy, 1985), much so for ecotourism which by design and philosophy, relies heavily on the host community. As Belanger (2006) suggests, tourism should also focus on the participation of and effects on the local populations of patronised areas. Host community capacities (individually and collectively) are critical in shaping the benefits that may accrue from tourism (Coria \& Calfucura, 2012; Koutra \& Edwards, 2012; Moreno, 2005) but in reality, the ability of typical SSA host communities to position themselves to take advantage of ecotourism opportunities has been severally questioned (Asiedu, 2002; Kiss, 2004; Boakye, 2008; Koutra \& Edwards, 2012). 
The typical SSA host community exhibits three capacity-related characteristics, which contrive to render them incapable of either withstanding the aforementioned shocks or profiting from economic opportunities that may arise from tourism development. The first is their heavy reliance on the immediate environment for sustenance (Ogutu, 2002; Lund, Dei, Boakye and Opoku Agyemang, 2008; Odincho 2010). Many rural poor people rely on forest resources (Coad et al. 2008). In Ghana for example, it is asserted that the country's socio-economic development and growth has, in the past, been achieved almost exclusively at the expense of the physical and non-physical environment (Forestry Commission, 2006).

In the specific case of the Kakum National Park Abane et. al. (1999) indicate that the surrounding communities relied heavily on the park for wood based products such as mortars, pestles, stools, drums chewing sticks, sponges and material for houses; Nutrition enhancing products such as snails, mushrooms, and game such as grass cutters, antelopes, rats and other meat sources; and medicinal products such as herbs, roots, tree barks and fruits. In addition, the delimitation of the park and the consequent reclamation of areas for conservation led to the shrinkage of cultivable land (Dei, 2000).

The second capacity-related trait relates to a lack of skills. Inhabitants of the typical SSA host community typically do not possess the relevant skills to become active participants in any tourism enterprise (Arthur and Mensah, 2006; Boakye, 2008, Koutra and Edwards, 2012). Normally, as is typical of such settings, those with skills migrate to bigger towns in search of non-existent formal jobs. Even in instances where, in the name of community engagement, certain job positions in the tourism establishment have been reserved for local people, their low skills preclude them from taking advantage of the opportunities thereby consigning them to subservient positions in their encounter with visitors (Mowforth \& Munt, 2003; Akyeampong, 2011) and the attendant low paying salaries.

Thirdly, inhabitants, of such communities tend to have little or no capital assets which can be leveraged to access credit. Hosting tourists creates many opportunities as each tourist need is an area for investment. However, owing to low credit and a low capital base, the majority of the inhabitants of these communities are unable to take advantage of such openings when they occur. Little credit implies limited abilities to pursue a viable alternative livelihood and culminates in an even greater degree of vulnerability because the dependence on the immediate environment has been curtailed.

The afore-mentioned conditions lead to a situation where the opportunities generated by tourism development are exploited mainly by more powerful outsiders in cohort with a few local elite (Zhang and Fang, 2004) as has been found variously on the African continent Namibia (Lapeyre, 2010), Ghana (Akyeampong, 2011) and south 
Africa (Mukwada and Dhlamini (2012). It is normally tempting to always conceptualize the core-periphery dichotomy at the inter-country level but in ecotourism the more detrimental power relations happen within the same local space where the resident elite dominate.

The literature is therefore summarised in the proposition that the vulnerability of SSA communities is not necessarily an outcome of the development of ecotourism per se but rather the result of their weak adaptive capacities occasioned by their socio-economic profile which makes them susceptible to the shocks of displacement and disruption of lifestyles. In the process they experience a lose-lose situation which obviously makes them disenchanted and antagonistic towards the ecotourism process. Perceptions of tourism in rural settings are a reflection of the level of their vulnerability which is itself informed by their resilience as shaped by their adaptive-capabilities to shock.

The study adopts a heuristic application of the SLF with an emphasis on assessing the shocks, assets, processes and outcomes of ecotourism-related development in the community. The ability of a system to react positively to shock or hazards is a direct function of its capacities.This thinking is what makes the Sustainable Livelihoods Framework (SLF) as outlined by Chambers and Conway (1992) relevant to the study. The SLF highlights the importance of identifying sources of shock and offers a framework to assess the coping mechanisms (including assets and processes) that are employed by communities to address shock. In the view of Ellis and Freeman (2004) a livelihoods approach is not just about income generation but human development, and not just to survive but to build capabilities. In spite of being heavily criticised, (de Haan and Zoomers, 2005) the concept still has relevance and is extensively used by both academics and development agencies.

Infusing the livelihoods approach into the study therefore, brings to fore the following issues: (1) shocks - what shocks have the people of Mesomagoro faced as a result of the creation of the KNP and how have they been managed? (2) Assets: what are the tourismrelated assets that the Mesomagoro community possesses and how have they been employed to enhance their adaptive capacities to boost their resilience to shock? And, (3) institutional processes. What institutions exist and what are their activities relative to building capacities?

\section{Method}

The study was carried out in Mesomagoro, a small farming community on the eastern fringes of the Kakum National Park in the Central Region in Ghana. The Mesomagoro township was designated as one of the project communities that the Ghana Heritage Conservation Trust chose to situate some tourism interventions such as the building of a 
tree house for observing elephants and the creation of a dance troupe. Mesomoagor was chosen primarily because it represents a departure from the general trend of negative sentiments among the communities surrounding the park. The study was carried out in December, 2015 and adopted a qualitative design to allow for a deeper situational and contextual understanding of the environment within which ecotourism development takes place Depoy and Gitlin (1998). A total of 25 respondents were chosen using the Purposive Sampling Technique. The respondents were chosen based on a combination of their respective roles and or positions in both the community and the ecotourism project. To that end the study covered two elders of the town, the local assembly representative, two members of the tourism management committee, four youth, two representatives each from other identifiable groups such as the women's group, and the 'visitors' (visitors in this context refers to the non-indigenes). In addition, two focus group discussions were held separately for 6 men and women each. Finally, the field project officer of the Ghana Heritage Conservation Trust, managers of the Project was also interviewed. As is typical with the qualitative design, the iterative process of simultaneous data collection and analysis implied that the unstructured interview would be the most appropriate tool for data collection. Common questions posed centred on issues regarding the shocks and benefits to their livelihoods that they had encountered as a result of the creation of the park as well as their views on supporting ecotourism and the reasons for such positions.

\section{Findings}

\section{Ecotourism-related Shocks}

The results identified four main ecotourism-generated shocks that the community has been exposed to, namely, destruction of their crops by elephants, a reduction in arable lands for farming, reduced access to the forest reserve and, an increase in the cost of their operations. Regarding the first of them, the destruction of crops, the respondents indicated that the creation of the park has caused the elephants to destroy their crops. This, it was explained, happened through the creation of a situation where in bid to avoid tourists, the human-shy forest elephants are 'forced' towards the fringes of the park where their farms are, and in the process, feed off their farms. One respondent's frustration summed it all up:

we are fed up of continuous suffering from these animals [ the elephants]. We have been stopped from using the forest. Can't we now farm in peace"? We have continually complained to the park authorities yet nothing concrete has been done so far. Farming has become difficult and unpredictable for us. [a farmer]. 
Another shock came in the form of reduction in access to arable lands for cultivation. The creation of the park had in their view reduced the land that was previously available to them for cultivation of various foodstuffs which they now have to purchase on the open market at prices they can hardly afford. A participant in the focus group had this to say:

My family had plenty of land so we were hardly buying any foodstuffs. But now the creation of the park has reduced the expanse of land and thus the quantity and quality of food we grow have reduced drastically [a focus group discussant].

The third shock relates to the disruption of their livelihoods. According to the respondents the creation of the Park had curtailed their access to resources they hitherto used for their economic activities. In instances where the same resources can now be found outside the park, it means a greater cost (at least by way of distance) to access them. The hardest hit in this regard were hunters and herbalists, as the ensuing quote suggests:

before the park (KNP) was created we used to get our daily supplies of food and medicines easily from the forest, but now we have to cover great distances to get them or even be prepared to buy them at exorbitant prices from the market. [a herbalist]

The fourth ecotourism-related shock pertained to the increased cost of production that the creation of the park had imposed on their businesses/livelihoods. To them, the restrictions imposed by ecotourism had translated into greater efforts and inputs required for their operations, which ultimately reduced their profits. A quote from the focus group discussions exemplifies this sentiment better:

Some of us are hunters and herbalists and used to get our supplies from within the forest area. Now that new boundaries have been set, we have to go farther away and sometimes for longer periods before we get similar catch" This has made our business unprofitable and rendered many of us redundant since the land we could use for farming is already scarce. [a hunter].

\section{Perceived Benefits of Ecotourism}

The shocks notwithstanding, there was a commonly held belief that the town had benefitted immensely from ecotourism. The major outcomes of the project as summarised by the GHCT and corroborated by the opinion leaders include:

1. Income from tourism related activities such as performances of the local dance group; booking of the tree-platform; a communally owned tourist guest house; entry fees for groups which represents an all-inclusive package of the hiking 
charge to the tree platform, a performance of the bamboo orchestra and locally cooked food.

2. Receipts were used to leverage counterpart funding from an NGO for the construction of a new school building

3. Again, part of the receipts were used to co-pay for the acquisition of pipe-borne water, and;

4. Indirect non-economic benefits arising out of their engagement with tourists such as adopting children for sponsorship, donations among others.

The following quotes support the views captured by the opinion leaders:

Through ecotourism we have been able to put up this school and get pipe borne water. For the many years before then the various governments were ignoring us. We didn't matter but now we have been able to raise our own money to solve our own problems. [an opinion leader].

Our town has become popular and we now have a sense of pride in what we have.

[an elder].

The training in cooking has also helped us as a group but also individually. We feel useful and we also have acquired better skills on nutrition that have helped us in our homes. [participant in womens's FGD discussion].

We now see the environment as our resource. We are committed to protecting it. We have ourselves imposed strict sanctions against any member who is caught entering the wildlife zone. We also support the work of the forestry commission people. [an opinion leader].

There were however, a few dissenting voices who felt ecotourism had not been beneficial as per the following quotes:

I don't see any benefits. This thing [ecotourism] has just come to make our lives miserable. We cannot go into the forest again, and we have to spend more money to get what we used to have for free from the forest"

Another said, ecotourism had "destroyed my farming business"

\section{Residents support for ecotourism and the reasons}

There is still widespread support for ecotourism (and by extension, the establishment of the Park). The ensuing quotes capture the sentiments better: 
Although we have some challenges, we are fully in support of ecotourism... as for the challenges they can be discussed and solved but we do not have any other alternative apart from ecotourism. [an opinion leader].

Generally, we have all agreed at our meetings that ecotourism should continue. The park has come to stay so we should make the best out of it... the elephants won't ever go away now that the government has established the park. So ours is to make the best out of the situation. [a focus group participant].

Generally, the study found that the reasons for their support were primarily economic, a few narratives are reproduced to buttress the point:

It is because of the benefits we are getting directly. We have all seen that if we help conserve the forest, people will want to come and walk through the forest [hike] and see the animals and once here, we can also perform and cook for them and we can use the proceeds to better our lives. [a non-indigene].

A female discussant of the FGD had this to say:

... Look we support it fully. Ecotourism has brought this village into the limelight ...... it has also helped us to sink two boreholes and we have even got a better school building now. What other activity could have given us all of these without a few people hijacking the proceeds?

Yet another had this to say:

It is because they (a reference to the park authorities) have created this Park that we have the white visitors who have also brought us money to have these things. [a focus group discussant].

Another reason for the support was the transparency and the degree of participation that the ecotourism had offered them:

We like this ecotourism because we can all decide what to do with the money.... as for this one a few people cannot sit somewhere and pocket the proceeds and deceive us. [a female opinion leader].

The idea of beneficence was again present in the reasons some gave for not supporting ecotourism:

"I had a fairly lucrative herbs business. But now I cannot go into the park for the herbs and I have to look for other ways of making a living and it's not easy. I know not many people support me but I wish we would go back to the forest"[herbalist] 
Yet another respondent had this to say on the same theme:

"The forest is meant for us to enjoy. Why should we keep it when we are suffering and it can help solve our problems? The money from tourism does not come directly to me so I do not see what benefits they are talking about. After all, we still pay some levies so where does all the tourism money go? [a focus group participant]

\section{Discussion}

The finding that the development of ecotourism had created some shocks for members of the Mesomagoro community is consistent with what is known from other studies. Other authors (e.g. Abane et. al. 1999 and Dei, 200o) have variously observed discontent among communities surrounding the park (including the study area). The fact that ecotourism development in rural settings creates shock has been well documented (e.g Monney et. al. (2010), Amoah and Wiafe (2012) of the KNP area as well as other parts of SSA such as in Kenya (Odinha, 2010; Ogutu, 2002), Congo (Cernea \& Schmidt-Soltau (2003), South Africa (Carruthers, 2007), Ethiopia (Pearce, 2005) and Botswana (Adams \& Hutton, 2007). In the specific case of Mesomagoro, the losses reflect a double-jeopardy situation because they involve both the disruption of livelihoods and, to add insult to injury, the destruction of their crops (especially subsistence ones like cassava, plantain and tomato), by the elephants. Though there have been attempts by the authorities to curb the elephant raiding, the problem still persists - an indication of the fact that the efforts are not yielding sustainable benefits.

Two noticeable traits of the Mesomagoro benefits are (1) their reflection of developmentoriented outcomes, (mainly income, education, health and sanitation) and (2) their widespread and sustained distribution within the community. In ecotourism, the accrual of benefits to the community is itself rare, and rarer still is such pluralistic distribution of same when they occur. As argued by the critical literature (e.g. Kiss, 2004; Laudati, 2010) the benefits of ecotourism in the developing world, if any, have been too small, skewed in distribution towards local elite and are generally not sustainable. Sustained communal benefits from ecotourism in SSA are few and far between.

The SLF Framework offers three factors that could account for Mesomagoro's sustained and widely-distributed benefits from tourism. These are; the presence of assets; the presence of a process that could transform these assets; and, the building of the capacity of the community to become active participants in the processes outlined. These three factors are discussed in turn: 


\section{The Presence of Assets}

Assets in this context were conceptualized as being tourism-related and are defined to include all resources that can be exploited for tourists' patronage. Mesomagoro's tourism assets can be classified to fall into two broad categories: tangibles and intangibles. The tangible tourism resources include the following:

Tangibles

- Wildlife Tree top platform used for overnight stay to view wildlife (especially elephants)

- $\quad$ Virgin forest used for hiking tours

- A farming culture

Intangibles

- $\quad$ Strong unadulterated culture especially, unique cultural dance - the Kukyekukyeku bamboo dance

- $\quad$ Proximity to KNP

- $\quad$ Hospitality (warm friendly reception for tourists)

\section{Processes}

The term 'processes' within the livelihoods framework refers to those institutions, actions and activities through which assets are transformed into resources for gain. In the case of Mesomagoro, the main initiator has been the Ghana Heritage Conservation Trust (GHCT). The GHCT is a non-profit organisation registered in both Ghana and the United States created to manage the transition of the USAID - sponsored Natural Resource Conservation and Historic Preservation Project into a regular organisation. Working in conjunction with the people of Mesomagoro, the GHCT transformed the assets by investing in the following:

- Construction of a treetop house for overnight stay by visitors who wish to see Elephants

- Development trails and folklore for the bamboo orchestra

- Building of a guest house for overnight stay.

\section{Capacity Building}

What is worthy of note is the fact that the capacity was built according to the strengths of the community. For each of the under listed capacity building initiatives some basic skill sets existed already. Perhaps this made the transition less difficult. 
- Training of the community women's group to cook various local dishes

- Training of tourguides for the forest hikes

- Training of the Kukyekukyeku cultural troupe and transforming it into a famous bamboo orchestra which uses musical instruments made from bamboo - a plant/ tree very common in the area.

- The creation and training of a Tourism Management Committee to coordinate the daily running of the project.

While many ecotourism projects may fulfil the first crtierion, it is the quality of the asset transformation and capacity building processes and revenue distribution methods that have made the Mesomagoro intervention a unique success. Akyeampong, (2011) argues that sustainable tourism development must simultaneously improve the product and enhance local livelihoods. Hence on account of these factors, the benefits have been created, sustained and widely distributed.

The generally positive view and strong support for further ecotourism can be attributed to the presence of the benefits and supports the long held assertion (e.g. Ap, 1992; Lee, 2013; Xu et. al. 2016) that the economic factor remains the overarching determinant of community support for ecotourism As noticed from the narratives, perceived benefits (or otherwise) influenced the respondents' views (either way) on support for ecotourism and conservation of the environment. Where ecotourism can provide tangible sustainable economic benefits at a lower opportunity cost, the potential for support is higher and vice versa. Such a viewpoint becomes more valid given the vulnerabilities and shocks described earlier in the paper.

\section{Towards Creating Viable Ecotourism Projects: Lessons from Mesomagoro}

The Mesomagoro success story provides four lessons which development planners who seek to use ecotourism as a pathway to development can learn from. The first lesson is that it is valuable to create viable complementary attractions in communities that surround major ecotourism projects. When thinking about attractions especially those with multiple settlements surrounding them, it is important for planners to fashion out feasible satellite attractions which are complementary to the main one for each of these communities. This is critical, as one recurring complaint among the other communities of the KNP is that tourists do not visit them (Dei, 2000; Boakye, 2008). Such attractions play two roles: first, they ensure a more equitable distribution of tourists and secondly, the attendant benefits help to reduce the vulnerability of such communities to ecotourism-related shock. The results from the study buttress this point. Mesomagoro's success owes largely to the presence of attractions which complement the main KNP. The 
success of the community's famous Kukyekukyeku bamboo dance troupe in attracting tourists to the village further emphasizes the importance of having complementary or satellite attractions relative to the main one. Through their unique performances, the dance troupe in addition to Tree-Top Platform and the forest hike constitute interesting attractions for ecotourists and cause a draw of visitors towards it.

Beyond attracting tourists, into the community, the second lesson is that the creation of these satellite attractions should be contextually relevant and financially feasible. The interventions must be based on competitive advantage as well as local competencies that can be easily absorbed. Sarkar and George, (2010) for instance, have found that simple enterprises that use skills, lifestyles and technologies that community members already possess are the most likely to be viable. The Mesomagoro experience shows that tourism was integrated into the local economy at two levels. At the first level, the services provided to tourists were those that fit into the already existing forms of livelihood. As noted by Amoah and Wiafe, (2012) and observed in the study, the community continues their main traditional occupations side by side hosting tourists. On the second level, the integration occurred through the creation of activities which were already a part of the community's existing skill sets. For example, the community members could more easily adapt to training that helped them to package their routine cultural activities (for example cooking and dancing) into a product as compared to being introduced to entirely new habits.

The third lesson highlights the need for ecotourism ventures/interventions to create benefits that are tangible and democratically accessible. As was noted from the study, the transformation of the community's resources into a viable tourism product created an outlet for revenue which, when accrued, was invested prudently in social infrastructure particularly the provision of a new school and potable drinking water. The nature of these investments made it possible not only to reach a wider number of beneficiaries, but, more importantly, for the community to tangibilise the benefits of conservation. Hence unlike in other communities where the benefits of tourism are not readily perceptible to the locals and skewed in favour of powerful interests (Kiss, 2004; Zhang \& Fang, 2004), the provision of these types of benefits in Mesomagoro made it easier for community members to see and feel the direct dividends of conserving the environment. The income from tourism may not be substantial, yet, owing to how the proceeds are being used, this project is unique in its ability to, at least, convince the community to positively perceive ecotourism and proactively protect the environment.

The fourth and final lesson draws from the way the Mesomagoro project has addressed the inescapable problem of skewed power and its attendant marginalisation of the larger community within the ecotourism context. As the study has found, the power skew was addressed through the creation of a functional and representative tourism management 
committee whose primary constituent was the larger community and not even the GHCT. Thus responsibility for decision making lies solely with the TMC which reports directly to the entire community and periodically renders accounts publicly to them. At such meetings, decisions on the use of the proceeds are taken. The TMC is responsible for managing the tourism process including receiving guest bookings, welcoming them to their community and coordinating their activities and service provision. Ordinarily the entry fees have been integrated to cover all the activities on offer including watching a performance by the bamboo orchestra, eating meals cooked by the women's group, and going on a two-hour hike in the forest led by a local tour guide thereby allowing for easier monitoring of income. Furthermore, the use of the proceeds to provide amenities that are not subject to individual manipulations has implied the elimination of potential domination.

\section{Conclusion}

There is no doubt that ecotourism development creates shocks for host communities. At the same time, it promises benefits that cannot be merely wished into being but must be realised through careful planning and implementation. The hardships that attend the development of ecotourism in rural communities can be mitigated when their adaptive capabilities are enhanced through the creation of communally-owned viable alternative income activities which produce benefits which are tangible and democratically accessible. There is the need to shift the debate from shocks towards, exploring the resilience and adaptive capacities of host communities. Communities that have weak capacities are prone to become more vulnerable from ecotourism-related shocks. Tourism development must be accompanied by capacity enhancement which itself must be the outcome of thorough needs assessment of the people and the fashioning of viable options for those who are directly affected by its costs. These findings are, however, to be extrapolated by caution as the nature of the research design places a limitation on drawing generalised conclusions based on the composition of the sample. A recent visit to the area suggests that the management structures are not as rigorous as captured at the time of the study. Changes in the political structure and the attendant reluctance of key actors to become accountable have culminated in a situation where there are early signs of tourism-related power blocks and disenchantment among the community. All the more these new developments only highlight the urgency of enhancing the capacity of host communities. 


\section{References}

Abane, M., Awusabo-Asare, K., Kissi, M. (1999). In whose interest? Individual and societal needs in the creation of forest reserves: The case of Kakum in Ghana. Bulletin of the Ghana Geographical Association, (21), pp. 21-30, Accra.

Adams,W.M. and Hutton, J. (2007). People parks and poverty: Political ecology and Biodiversity Conservation. Conservation and Society, 5 (2), pp. 147-183.

Akyeampong, O. A. (2011). Pro-poor tourism: residents' expectations, experiences and perceptions in the Kakum National Park Area of Ghana. Journal of Sustainable Tourism, 19 (2), pp. 197-213.

Amoah, M. Wiafe, E.D. (2012). Livelihoods of fringe communities and the impacts on the management of conservation area: the case of Kakum National Park in Ghana. International Forestry Review, 14 (2), pp. 131-144.

Amuquandoh, F. E. (2010). Lay concepts of tourism in Bosomtwe Basin, Ghana. Annals of Tourism Research, 37 (1), pp. 34-51.

Ap, J. (1992). Residents' perception research on the social impacts of tourism. Annals of Tourism Research, 11 (4), pp. 610-616.

Arthur, S.N. and Mensah, J.V. (2006). Urban management and heritage tourism for

sustainable development: The case of Elmina Cultural Heritage and Management Programme in Ghana. Management of Environmental Quality: An International Journal, 17 (3), pp. 299-312.

Asiedu, A. B. (2002). Making Ecotourism more Supportive of Rural Development in Ghana West African Journal of Applied Ecology (3), pp. 1-18.

Belanger, K. (2006). Ecotourism and its effects on native populations (online). Available at http://www.geog.umd.edu/academic/undergrad/harper/kbelanger. pdf. Accessed 20 December, 2015.

Boakye, K. A. (2008). Ecotourism, national parks and biodiversity conservation in Africa, in E. Boon, (Ed.), Management of national parks and biodiversity conservation in Africa, pp. 47-62. Delhi: Kamla-Raj.

Boo, E. (1990). Ecotourism - The potentials and pitfalls (Vol. 1). Lancaster: Wickersham Printing Company.

Blackstock, K. (2005). A critical look at community based tourism. Community Development Journal, 40 (1), pp. 39-49.

Burns, P.M. (2004). Tourism planning: A third way? Annals of Tourism Research, 31 (1), pp. 24-43. 
Carruthers, J. (2007). South Africa: A world in one country: Land restitution in national parks and protected areas. Conservation and Society 5 (3), pp. 292-306.

Coad, L., Campbell, A., Miles, L., Humphries, K. (2008). The Costs and Benefits of Protected Areas for Local Livelihoods: a review of the current literature. Cambridge, U.K: Working Paper. UNEP World Conservation Monitoring Centre.

Coriaa, J. and Calfucurab, E. (2012). Ecotourism and the development of indigenous communities: The good, the bad, and the ugly. Ecological Economics, 73, pp. 47- 55.

Cernea, M.M. (2006). Re-examining "Displacement": A redefinition of concepts in development and conservation policies. Social Change, 36 (1), pp. 8-35.

Cernea, M. M. and Schmidt-Soltau, K. (2003). The end of forcible displacement? Conservation must not impoverish people. Policy Matters, 12, pp. 42-51.

Chambers, R. (1989). Editorial introduction: Vulnerability, coping and policy. IDS Bulletin 20 (2), p. 7.

Chambers, R. and Conway, G. (1992). Sustainable Rural Livelihoods: Practical concepts for the 21st Century. IDS Discussion Paper 296, IDS, Brighton, UK.

Cobbinah, P.B. Black, R. and Thwaites, R. (2015). Ecotourism implementation in the Kakum Conservation Area, Ghana: Administrative framework and local community experiences. Journal of Ecotourism, 14 (2-3), pp. 223-242.

Dei, L. A. (2000). Community participation in tourism in Africa. In P.U.C., Dieke, (Ed.). Political economy of tourism in Africa, pp. 285-289. NY: Cognizant Corporation.

Depoy, E. and Gitlin, L. (1998). Introduction to research. Understanding and applying multiple strategies. New York: Mosby.

Eshun, E. (2011). Ecotourism Development in Ghana: A Postcolonial Study with Focus on Boabeng-Fiema Monkey Sanctuary and Kakum National Park. (online). Available at:https://1ra.le.ac.uk/jspui/bitstream/2381/9175/1/2011eshungphd. pdfhttps://lra.le.ac.uk/jspui/. Accessed: $20^{\text {th }}$ December, 2012.

Eshun, G. and Tagoe-Darko, E. (2015). Ecotourism Development in Ghana: A Postcolonial Analysis. Development Southern Africa, 32 (3), pp. 392-40 European Commission (2010). Evaluating African Protected Areas (online). Available at: http://www.earthobservations.org/documents/sbas/ec/87_Evaluating\%20 African\%20Protected\%20Areas.pdf/. Accessed 1 January, 2013.

Forestry Commission. (2006). Annual Report (2005). Accra: Forestry Commission.

Honey, M. (1999). Ecotourism and Sustainable Development. Who owns Paradise? Washington: Island Press. 
Honey, M., and Gilpin, R. (2009). Tourism in the Developing World: Promoting Peace and Reducing Poverty. Washington: United States Institute for Peace.

Kiss, A. (2004). Is a Community-based Ecotourism a good use of Biodiversity Conservation fund? Ecology and Evolution, 19 (4), pp. 232-256.

Koens, J. F., Dieperink, C. and Miranda, M. (2009). Ecotourism as a development strategy: experiences from Costa Rica. Environ Dev Sustain, 11, pp. 225-1237.

Koutra, C. and Edwards, J. (2012). Capacity building through socially responsible tourism development. A Ghanaian Case Study. Journal of Travel Research 51 (6), pp. 779-792.

Kuenzi, C. and McNeely, J. (2008). Nature-based tourism. In: O. Renn and K.D.Walker (eds.). Global Shock Governance: Concept and Practice Using the IRGC Framework International Shock Governance Council Bookseries, Springer, The Netherlands, pp. $155-178$.

Lapeyre, R. (2010). Community-based tourism as a sustainable solution to maximize impacts locally? The Tsiseb Conservancy case, Namibia. Development Southern Africa 27 (5), pp. 757-772.

Lasgorceix, A. and Kothari, A. (2009). Displacement and relocation of protected areas: A synthesis and analysis of case studies. Economic \& Political Weekly, xliv (49), pp. 38-47.

Laudati, A. (2010). Ecotourism: The modern predator? Implications of gorilla tourism on local livelihoods in Bwindi impenetrable national park, Uganda. Environment and Planning D: Society and Space, 28 (4), pp. 726-743.

Lee, T.H. (2013). Influence analysis of community resident support for sustainable tourism development. Tourism Management, 34(1), pp. 37-46.

Lund, R., Dei, L.A., Boakye, K.A., and Opoku-Agyamang, E. (2008). It is all about livelihoods: A study of women working in stone chip production in Cape Coast Municipality, Ghana, Norwegian Journal of Geography, 62 (3), pp. 139-148.

Mason, J. and Danso, E. (1995). PRA for people and parks: the case of Mole National Park, Ghana. PLA Notes, 22, pp. 76-79, London: IIED.

McLaughlin C.M. (2011). People living in protected areas: A comparative study of the social impacts of conservation in Latin america冈s mamirau sustainable development reserve And $\mathrm{r}$ a celest $\mathrm{n}$ biosphere reserve (online). Available at http:// www.american.edu/sis/gep/upload/o8_2011_McLaughlin_SRP.pdf. Accessed January 3, 2013.

Moreno, P. (2005). Ecotourism along the Meso-American Caribbean Reef: The impacts of foreign investment. Human Ecology, 33 (2), pp. 217-244. 
Monney, K.A, Dakwa, K. B. and Wiafe, E.D. (2010). Assessment of crop raiding situation by elephants (Loxodonta africana cyclotis) in farms around Kakum conservation area, Ghana. International Journal of Biodiversity and Conservation, 2 (9), pp. 243-249.

Mowforth, M. and Munt, I. (2003). Tourism and Sustainability. Development and New Tourism in the Third World, ( $2^{\text {nd }}$ ed.). New York: Routledge, pp. 37-43.

Mukwada, G. and Dhlamini, S. (2012). Challenges of event tourism in local economic development: The case of Bethlehem, South Africa. J Hum Ecol 39 (1), pp. 27-38.

Pleumarom, A. (2012). The politics of tourism, poverty reduction and sustainable development. Penang: Third World Network.

Nelson, F. (2012). Blessing or curse? The political economy of tourism development in Tanzania. Journal of Sustainable Tourism 20 (3), pp. 359-375.

Sarkar, S.K. and George, B.P. (2010). Peace through alternative tourism: case studies from Bengal, India. Journal of Tourism and Peace Research, 1(1), pp. 27-41.

Schmidt-Soltau, K. (2005). The environmental shocks of conservation related displacements in central Africa. In I. Ohta and Y. D. Gebre, (Eds.), Displacement shocks in Africa, pp. 282-311. Melbourne: Trans PacificPress.

Torri, M.C. (2011). Conservation, relocation and the social consequences of conservation policies in protected areas: Case study of the Sashocka Tiger Reserve, India. Conservat Soc, 9 (1), pp. 54-64.

Twerefour, D.K. and Ababio D. K. A. (2012). An economic valuation of the Kakum National Park: An individual travel cost approach. African Journal of Environmental Science and Technology 6(4), pp. 199-207.

Xu, S., Barbieri, C., Anderson, D., Leung, Y.F. and Rozier-Rich, S. (2016). Residents' perceptions of wine tourism development. Tourism Management, 55, pp. 276-286.

Zhang, Y. and Fang, K. (2004). Is history repeating itself? From urban renewal in the United States to inner-city redevelopment in China. Journal of Planning Education and Research, 23, pp. 286-298. 